\title{
EFFECT OF DIFFERENT PROTEIN AND/OR METABOLIZABLE ENERGY LEVELS IN DIETS FORMULATED BASED ON IDEAL PROTEIN CONCEPT ON PERFORMANCE, EGG PRODUCTION, AND EGG QUALITY TRAITS OF LAYERS DURING PHASE 1 OF EGG PRODUCTION
}

\author{
Shaimaa R. Anwar ${ }^{1} \rrbracket$, Ahmed A. Al-Sagan ${ }^{2}$, El- Bannaa, R. A ${ }^{1}$. and Melegy, T. M ${ }^{1}$ \\ ${ }^{1}$ Department of Nutrition and Clinical Nutrition- Faculty of Veterinary Medicine Cairo-University, Giza 12211, \\ Egypt. \\ ${ }^{2}$ King Abddulaziz City for Science and Technology, Riyadh, Saudi Arabia.
}

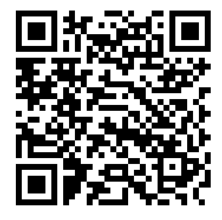

Received 14 September 2021

Accepted 15 October 2021

Published 30 October2021

\section{Corresponding Author}

Shaimaa R. Anwar,

vetsh.sr@gmail.com

DOI

10.29121/granthaalayah.v9.i10.2021 .4301

Funding: This research received no specific grant from any funding agency in the public, commercial, or not-for-profit sectors.

Copyright: (C) 2021 The Author(s). This is an open access article distributed under the terms of the Creative Commons Attribution License, which permits unrestricted use, distribution, and reproduction in any medium, provided the original author and source are credited.

\section{ABSTRACT}

A comparative study was conducted to determine the impacts of crude protein (CP) reductions in laying hen diets. During phase one of egg production, 270 laying hens were randomly assigned into six dietary treatments, which were replicated three times using a $2 \times 3$ factorial experiment. Reduced $\mathrm{CP}$ and metabolizable energy (ME) diets were formulated based on the ideal amino acid profile concept and supplemented with crystalline amino acids. The control treatment received standard commercial diets containing $18.8 \% \mathrm{CP}$ and $2,725 \mathrm{kcal} / \mathrm{kg} \mathrm{ME}$. Average weight gain, hen day egg production percentage, egg weight, egg mass, and other selected egg quality parameters were recorded. Data were statistically analyzed. Feed consumption and the feed conversion ratio were improved in birds fed reduced $\mathrm{CP}$ diets supplemented with crystalline amino acids. The dietary CP level significantly influenced shell thickness (ST), while the dietary ME level had no effect. A highly significant interaction was observed between CP percent and the Haugh unit (HU). Results indicate that the "ideal protein concept" may be followed as an economically feasible option for laying hens since it optimizes the dietary amino acid profiles and ME levels, and have a positive effect on hen growth, egg quality and environmental pollution.

Keywords: Amino Acid Profile, Egg Quality, Feed Consumption, Haugh Unit, LohmanLSL, Reduced CP

\section{INTRODUCTION}

The poultry industry strives to achieve maximum performance from poultry, while minimizing cost and environmental contamination. The establishment of a competitive and profitable egg production system is a complicated matter that challenges the laying hen industry. Increasing the dietary protein intake of laying hens is expensive, and it increases environmental nitrogen emission levels. Excretion, the volatilization of dietary nitrogen, and the emission of volatile organic compounds contribute most to environmental problems from intense layer production Keshavarz et al. (1992). However, egg production could be increased by raising the protein content in hen diets, while reducing the diet's energy content Ding et al. (2016), Yu et al. (2008), Rose et al. (2004). Increasing the crude protein (CP) content of hen diets increases egg production Mousavi et al. (2013), Gunawardana et al. (2009), Zanaty (2006), egg mass, and the feed conversion ratio Mousavi et al. (2013), Nahashon et al. (2007), Liu et al. (2005). 
Nitrogen excretion can be decreased by formulating the diet of laying hens based on their amino acid rather than $\mathrm{CP}$ requirements and lowering their total dietary nitrogen intake. Low CP diets can be formulated by partially substituting soybeans with corn and crystalline amino acids or an amino acid analog Patterson (2001). Adding discrete crystalline amino acids to the diet permits a more accurate formulation that satisfies the layers' requirements, and diets with lower amounts of excess amino acids result in lower amounts of amino acids being deaminated and lower amounts of nitrogen being converted into excreted uric acid Summers (1993), Summers and Leeson (1994).

This study investigated the influence of reduced protein and/or ME contents on the zootechnical and egg quality parameters of laying hens. The experimental results provide specific and practical feed formulas that can be used by layer producers as a reference guide to regulate the amino acid profiles and calorie content of their hen diets, maintaining layers at their optimal weight.

\section{MATERIAL AND METHODS}

This feeding trial was conducted at Henz farm on the Cairo-Alexandria Road. The research on animals was performed according to the International Animal Care Institute Committee of Cairo University (IACUC) on animal use (IF-CU).

\section{Birds, diets, and experimental design}

The current experimental trial was carried out at Henz farm located in Egypt, Cairo governorate, Cairo-Alexandria desert road. After a two-week preliminary period, 270 Lohmann-LSL laying hens (26-28 weeks of age) were randomly assigned one of six dietary treatments, with 45 hens/group, in a random block design, with each block containing three replicates (15 bird/replicate) and three adjacent cages representing a replicate. The experimental design was $2 \times 3$ factorial. Six experimental corn-soy-based diets were formulated on the basis of the ideal protein concept (SID A.A.) to meet the nutrient requirements and amino acid profile of the Lohmann-LSL laying hens breed, as recommended by the breed manual. The diets contained two levels of dietary ME (2725 and $2625 \mathrm{kcal} / \mathrm{kg})$ and three levels of dietary CP

\begin{tabular}{|c|c|c|c|c|c|c|}
\hline Ingredients & CG1* & G1L** & G2* & G2 $\mathbf{L}^{* *}$ & G3* & G32** \\
\hline Yellow corn & 53.05 & 49.26 & 56.60 & 52.82 & 60.21 & 56.23 \\
\hline Soybean meal (46\%) & 18.94 & 19.55 & 19.05 & 19.66 & 19.16 & 19.39 \\
\hline Corn gluten meal (60\%) & 7.66 & 7.68 & 4.62 & 4.64 & 1.53 & 1.69 \\
\hline Soybean oil & 1.52 & 1.64 & 1.58 & 1.70 & 1.65 & 1.75 \\
\hline Wheat bran & 6.25 & 6.25 & 5.45 & 5.45 & 4.64 & 5.24 \\
\hline Filler & 0.00 & 3.06 & 0.00 & 3.05 & 0.00 & 2.89 \\
\hline Met & 0.09 & 0.10 & 0.15 & 0.16 & 0.21 & 0.22 \\
\hline L-Lys-HCL & 0.02 & 0.01 & 0.05 & 0.04 & 0.07 & 0.07 \\
\hline
\end{tabular}




\begin{tabular}{llllllll} 
Thr & 0.00 & 0.00 & 0.00 & 0.00 & 0.02 & 0.02 \\
\hline Sodium bicarbonate & 0.32 & 0.31 & 0.34 & 0.33 & 0.36 & 0.35 \\
\hline Choline Chloride 60\% & 0.11 & 0.10 & 0.11 & 0.10 & 0.11 & 0.10 \\
\hline Salt (NaCl) & 0.19 & 0.17 & 0.18 & 0.19 & 0.18 & 0.18 \\
\hline Monocalcium phosphate & 1.44 & 1.44 & 1.46 & 1.47 & 1.48 & 1.48 \\
\hline Limestone (CaCo3) & 9.91 & 9.90 & 9.90 & 9.90 & 9.90 & 9.90 \\
\hline Premix & & & & & & & \\
\hline TOTAL & 0.50 & 0.50 & 0.50 & 0.50 & 0.50 & 0.50 \\
\hline & 100.00 & 100.00 & 100.00 & 100.00 & 100.00 & 100.00 \\
\hline
\end{tabular}

(18.8\%, 17\%, and 15.5\%). Each experimental group remained on their assigned diet for the three month (28-40 weeks of age) experimental period. Diet composition, supplemented amino acid levels, and calculated concentrations are shown in Table 1 and Table 2.

*Represent the group fed the same level of CP\% but with high ME $(2,725$ $\mathrm{Kcal} / \mathrm{kg}),{ }^{* *}$ Represent the group fed the same level of CP\% but with low ME $(2,625$ $\mathrm{Kcal} / \mathrm{kg}$ ), ${ }^{* * *}$ Lay Mix-Rannim each 1 kg contains: Vit. A: 25 MIU, Vit. B1: 2 g, Vit. B2: 10 g, Calcium D Pantothenate: 16 g, Vit. B6: 3 g, Vit. B12: 0.032 g, Vit. D: 35 MIU, Vit. E: 16 g, Vit. K: 2 g, Niacin 24 g, Folic acid: 2 g, Organic Base Q.S.

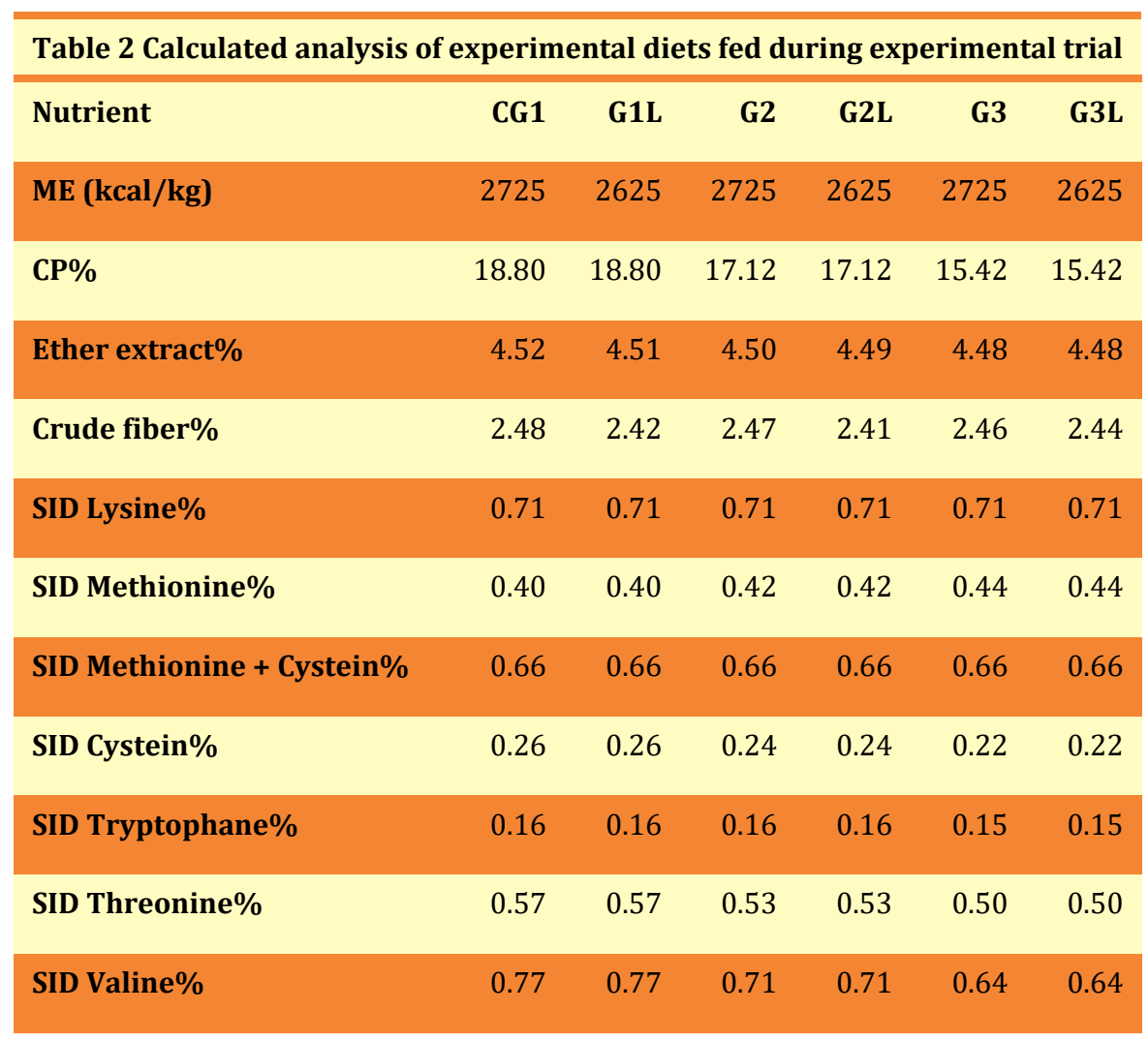




\begin{tabular}{lccccccc}
\hline SID Isoleucine\% & 0.69 & 0.69 & 0.63 & 0.63 & 0.57 & 0.57 \\
\hline Calcium\% & 4.10 & 4.10 & 4.10 & 4.10 & 4.10 & 4.10 \\
\hline Phosphorus(total)\% & 0.66 & 0.66 & 0.65 & 0.65 & 0.64 & 0.64 \\
\hline Phosphorous (available) & 0.42 & 0.42 & 0.42 & 0.42 & 0.42 & 0.42 \\
\hline Sodium\% & 0.18 & 0.18 & 0.18 & 0.18 & 0.18 & 0.18 \\
\hline Cl\% & 0.18 & 0.18 & 0.18 & 0.18 & 0.18 & 0.18 \\
\hline K\% & 0.60 & 0.60 & 0.60 & 0.60 & 0.60 & 0.60 \\
\hline SID = Standard ilealy digestible amino acid basis & & & & \\
\hline
\end{tabular}

\section{Measurements, observations, and statistical analysis Performance parameters}

Five birds per replicate were weighed biweekly, and FC was calculated biweekly. Then, final weight gain and feed conversion ratios were calculated (g feed/g egg mass). The production and production percentage of eggs per hen were determined daily and expressed as HDEP per treatment. Additionally, the average egg weight (g) (AEW) for each treatment was determined each month. Egg mass (g/hens) (EM) was determined by multiplying the weight of the egg by the percentage of eggs produced. Protein intake (g) (PI), ME intake (kcal/kg) (ME I), lysine intake (g) (Lys. I), and methionine + cysteine intake (g) (Met. + Cys. I) for each dietary treatment were also calculated.

\section{Egg quality analysis}

Nine eggs from each experimental group were collected monthly and weighted. Then, they were examined externally and internally for egg quality parameters, including egg specific gravity (ESG), yolk height, albumin height, yolk diameter, albumin diameter, and (ST) in mm. Egg shell weight (ESW), yolk weight (YW), and albumin weight (AW) were determined in g following Shaimaa et al. (2015). The (HU) was calculated following Larbier and Leclercq (2000).

\section{Economic efficiency}

At the end of the experimental trial, the economic efficiency of all six diets was analyzed to determine whether they were economically viable for practical use.

\section{Statistical analysis}

Statistical analysis was conducted using IBM SPSS Statistics 16.0 software. The obtained data were presented as the mean per treatment and standard error of the mean. Variance analysis was conducted via a two-way ANOVA test with CP percentages and ME levels (kcal/kg) as the fixed factors. Schefft tests were performed to test for the presence of significant interactions. Statistical significance was indicated at $\mathrm{p}<0.05$. Correlation coefficient analysis among performance variables and between performance variables and egg quality traits were computed using the Minitab 17.0 (Minitab, Inc, USA) statistical program. 


\section{RESULTS AND DISCUSSIONS}

\section{Performance parameters}

The production performance parameter results are shown in (Table 3). Correlation coefficient statistical analysis results show the interactions between the performance parameters from different dietary treatments and are presented in (Table 4). The results showed that both CP percentage and ME content did not significantly $(p>0.05)$ influence AWG. There were also no significant interactions observed ( $p>0.05$ ) between the different CP percentages and ME levels, and AWG. The insignificant effect of the higher level of dietary ME $(2,725 \mathrm{kcal} / \mathrm{kg})$ on AWG that we observed was not in agreement with Gunawardana et al. (2008), who claimed that higher levels of dietary energy had a significant linear impact on weight gain. These contradicting results might be due to differences in experimental conditions, such as the degree of CP reduction, which was greater in this study, (17 and $15.5 \%$ vs $10 \%)$. They could also be the result of differences in the stages of production found in each study, as this study was 115 conducted during the later stage of production. Some researchers have reported, however, that reduced CP diets did not adversely affect performance parameters Ji et al. (2014), Novak et al. (2006), Koelkebeck et al. (1993). In this study, a significant ( $<$ 0.05) interaction was registered between the CP percentage and EW. Since protein is one of the main components of eggs Leeson et al. (2000), it is possible that the higher CP content diets may lead to a greater CP deposition in the eggs. The lack of significant interactions between diets with high levels of ME and EW is supported by the findings of Summers and Leeson (1983), who concluded that dietary energy levels in laying hen diets had no influence on EW. Nevertheless, several authors pointed out that increasing dietary energy levels produced heavier eggs Wu et al. (2005), Sohail et al. (2003), Bohnsack et al. (2002). Correlation coefficients (Table 4) in this study were significantly positive $(\mathrm{p}<0.05)$ between EW and PI, ME I and Lys. I, $(\mathrm{r}=$ $0.84,0.82$ and 0.89 , respectively). Moreover, there was a non-significant positive correlation coefficient between HDEP\% and EW, which is in contrast with Nahashon et al. (2007), who observed that there was an insignificant negative correlation between HDEP and EW. The obtained positive correlation between Lys. I and EW coincides with the findings of Zimmerman and Andrews (1987), who noticed that EW is improved by increasing the dietary level of lysine. Additionally, it can be observed that HDEP\% decreased in G3 containing $15.5 \%$ CP by $0.52 \%$ and $1.35 \%$, compared to the higher levels of CP (18.8\% and $17128 \%$, respectively). Meanwhile, the combined effect of lowering both the CP percentage and ME (Table 3) levels on HDEP\% was more severe, as HDEP\% declined by $7.1 \%$ and $7.9 \%$ in G3L compared with CG1 and G2, respectively. Additionally, CP percentage and ME levels had a significant effect $(p<0.05)$ on HDEP\%, and a highly significant interaction $(p<0.01)$ was observed between $\mathrm{CP}$ percentage, $\mathrm{ME}$, and $\mathrm{CP}$ percentage * ME levels on $\mathrm{HDEP} \%$ and EM. The correlation between FC and HDEP \% (Table 4) was a weak positive correlation, which seems logical, as more feed is needed to get more eggs Olorede (1998), Aduku (2004). The highly significant $(\mathrm{p}<0.01)$ positive correlation $(\mathrm{r}=$ 0.93) between HDEP and EM agreed with Nahashon et al. (2007) and was supported by the positive significant $(\mathrm{p}<0.05)$ correlation between EW and EM (Table 4). Conversely, Almeida et al. (2012) concluded that EM was greater with diets containing $18 \% \mathrm{CP}$, as compared to diets containing $15 \% \mathrm{CP}$. The overall $\mathrm{FC}$ results (Table 3 ) reveal that FC significantly increased $(\mathrm{p}<0.05)$ when dietary ME was lowered from 2,810 to $2,710 \mathrm{kcal} / \mathrm{kg}$. 137 These results were not in agreement with the findings of Nahashon et al. (2006), Nahashon et al. (2007), who claimed that FC was not affected by a narrow increase 138 of dietary ME (100 kcal $/ \mathrm{kg})$, 
nevertheless, the increase in ME levels over $100 \mathrm{kcal} / \mathrm{kg}$ induced significant increases in FC Nahashon et al. (2006), Grobas et al. (1999). Regarding the impact of the dietary CP percentage reduction on overall $\mathrm{FC}$, it is to be concluded that reducing dietary $\mathrm{CP} 140$ levels by $3.3 \%$ from $18.8 \%$ to $15.5 \%$, even with a constant energy level, had a significant ( $p<0.05$ ) negative impact on FC. Moreover, the 141 positive influence of high dietary CP levels on FC was supported by the highly significant $(\mathrm{p}<0.01)$ positive correlation coefficients between FC 142 and PI, Lys. I and met. + Cys. I (Table 4). Different dietary CP and ME levels had an insignificant ( $p>0.05$ ) impact on FCR (g feed/g EM). 143 Nevertheless, birds fed diets containing $15.5 \%$ CP consumed less than layers fed diets contained $17 \%$ and $18.8 \%$ CP, which resulted in a higher 144 FCR in layers fed the $15.5 \%$ CP diets, as compared to other dietary treatments. 145 In agreement with the results of this study, several authors reported that performance parameters were not significantly affected when laying 146 hens were fed diets containing varying CP and /or ME levels at different phases of the productive cycle Summers and Leeson (1983), Sell et al. (1987), Keshavarz (1998). In contrast, Nahashon et al. (2007), showed that laying hens receiving $14 \%$ $\mathrm{CP}$ diets displayed better performance 148 parameters than those receiving diets with higher CP levels (18\% and $16 \%$ ), which might be the result of high energy expenditures in the excess 149 dietary amino acid catabolism of diets with higher levels of CP (18\% and $16 \%)$.

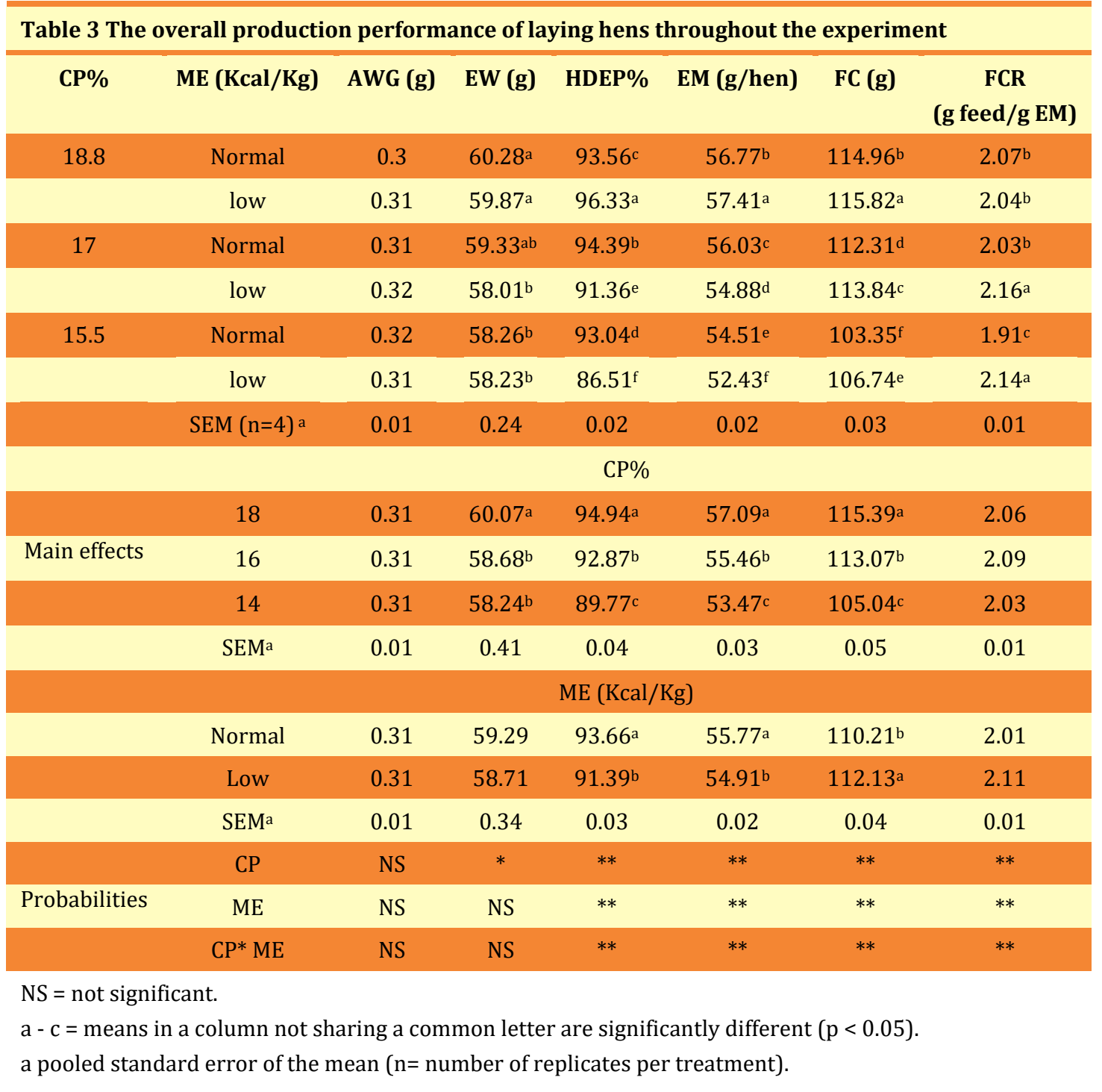




\begin{tabular}{|c|c|c|c|c|c|c|c|c|}
\hline Parameter & FCR (g feed /g egg mass) & ME I (Kcal \Kg) & $\begin{array}{l}\text { PIa } \\
\text { (g) }\end{array}$ & $\begin{array}{l}\text { Lys.Ia } \\
\text { (g) }\end{array}$ & $\begin{array}{l}\text { Met. + cys.Ia } \\
\text { (g) }\end{array}$ & HDEP\% & EW (g) & $\begin{array}{c}\text { EM } \\
\text { (g/hen) }\end{array}$ \\
\hline FC (g) & 0.473 & $0.903^{* *}$ & $0.96^{* *}$ & $0.92^{* *}$ & $0.97^{* *}$ & 0.51 & 0.69 & 0.752 \\
\hline $\begin{array}{c}\text { FCR } \\
\text { (g feed/g egg mass) }\end{array}$ & & 0.19 & 0.27 & 0.26 & 0.53 & -0.48 & -0.11 & -0.2 \\
\hline СР\% & & $0.92^{* *}$ & $0.99 * *$ & $0.98^{* *}$ & $0.88^{*}$ & 0.69 & $0.87^{*}$ & $0.89^{* *}$ \\
\hline $\begin{array}{c}\text { ME } \\
\text { (Kcal kg) }\end{array}$ & & 0.23 & -0.06 & -0.04 & -0.17 & 0.37 & 0.29 & 0.26 \\
\hline $\begin{array}{c}\text { EM } \\
\text { (g/hen) }\end{array}$ & & $0.86^{*}$ & $0.87^{*}$ & $0.84^{*}$ & 0.65 & $0.93^{* *}$ & $0.83^{*}$ & \\
\hline HDEP\% & & 0.73 & 0.74 & 0.65 & 0.49 & & 0.55 & \\
\hline EW (g) & & $0.82^{*}$ & $0.84^{*}$ & $0.89^{* *}$ & 0.72 & & & \\
\hline $\begin{array}{c}\text { PIa } \\
\text { (g/hen/day) }\end{array}$ & & $0.93^{* *}$ & & $0.98^{* *}$ & $0.91^{* *}$ & & & \\
\hline $\begin{array}{l}\text { ME I } \\
\text { (Kcal \Kg) }\end{array}$ & & & & $0.89 * *$ & $0.89 * *$ & & & \\
\hline $\begin{array}{c}\text { Lys.Ia } \\
\text { (g/hen/day) }\end{array}$ & & & & & $0.90^{* *}$ & & & \\
\hline $\begin{array}{l}* \mathrm{P}<0.05 ;{ }^{* *} \mathrm{P}<0.01 \\
\text { a Standard ilealy diges } \\
\mathrm{FCR}=\text { feed conversion } \\
\mathrm{PI}=\text { protein intake, } \mathrm{Ly}\end{array}$ & $\begin{array}{l}\text { table amino acid basis } \\
\text { ratio, EM = egg mass, HDEP = } \\
\text { s. I = lysine intake, Met + Cys } \\
* \mathrm{P}<0.05,{ }^{* *} \mathrm{P}<0.0 \\
\mathrm{AWG}=\text { average wei } \\
\mathrm{FC}=\text { feed consumpt }\end{array}$ & $\begin{array}{l}\text { = hen day egg prod } \\
\mathrm{I}=\text { methionine }+ \\
\text { l. } \\
\text { ght gain, EW = egg } \\
\text { ion, FCR = feed con }\end{array}$ & $\begin{array}{l}\text { lction, } \\
\text { ystine in } \\
\text { weight, } \mathrm{H} \\
\text { version r }\end{array}$ & $\begin{array}{l}\text { ake. } \\
\text { DEP = he } \\
\text { atio. }\end{array}$ & day egg prod & ction, EM & egg mass, & \\
\hline
\end{tabular}

\section{Egg quality traits}

The external and internal egg quality traits areshown in (Table 5). The results of the statistical correlation coefficient analysis between the performance parameters and egg quality traits in the various studied dietary treatments are presented in Table 6. Regarding the external egg quality traits (ESG and ESW), CP percentage had a significant influence $(\mathrm{p}<0.05)$ on ESG, which was confirmed by the significant positive interaction $(\mathrm{p}<0.05)$ of CP percentage on ESG. On the other hand, neither CP percentage nor ME levels showed an interaction with ESW. These results demonstrate that dietary CP levels had more of a significant impact $(\mathrm{p}<0.05)$ on ST than dietary ME levels, which was confirmed by the highly significant interaction $(\mathrm{p}<0.01)$ between dietary CP percentage and ST, as well as the highly significant $(\mathrm{p}<0.01)$ positive correlation coefficients between ST and PI, Lys. I and 
met. + Cys. I (Table 6). Moreover, significant interactions ( $\mathrm{p}<0.05)$ were found between ME, CP* ME, and ST. In accordance with our results, Nahashon et al. (2007), observed that the ST of laying hens was markedly affected by dietary energy levels, and birds that consumed lower levels of ME (2,800 vs. 2,900 kcal/kg) had significantly higher ST than birds that consumed higher levels of ME. The positive correlation between TSAA and ST was described by Simkiss and Taylor (1971), who suggested that this relationship is because TSAA is important for raising the calcium binding efficiency of the eggshell protein matrix, and thus enhancing the eggshell thickness and egg quality. Regarding the results of the internal egg quality (Table 5), the main CP percentage effect was significant $(p<0.05)$ on both AI and HU. A highly significant $(\mathrm{p}<0.01)$ interaction was observed among CP percentage, CP * ME, and $\mathrm{AI}$ as well as between the CP percentage and HU. On the contrary, Zimmermann and Andrews (1987) mentioned that dietary energy and protein level reductions had no effect on HU units, while Mendonca and Lima (1999) observed no effect of reduced protein levels on the albumen quality of eggs. Nevertheless, Almeida et al. (2012) suggested that, although HU scores were not influenced by dietary ME levels, higher levels of CP lowered HU unit scores, compared to reduced CP diets (15\%), which might be related to the fact that higher egg weights were recorded for the hens in the $18 \%$ CP treatment. Additionally, dietary CP percentage significantly $(\mathrm{p}<0.05)$ influenced AW. Similarly, a highly significant interaction $(\mathrm{p}<0.01)$ was noticed between $\mathrm{CP}$ percentage and AW. These positive relationships were also described by Novak et al. (2004), who claimed that raising TSSA and lysine intake levels of layers on a daily basis would significantly affect albumen weights. The same authors (2006) reported that egg traits were affected by CP intake, however, the TSAA: Ly's ratio and solid albumen percentage linearly decreased as protein intake was reduced. This might be one of the factors associated with the decrease in egg weight. These results are partially consistent with the findings of Novak et al. (2006), as AW displayed a linear decrease with dietary $\mathrm{CP}$ reduction at a high ME level. The highly significant positive $(\mathrm{r}=0.89, \mathrm{p}<0.01)$ correlation was observed between YW and ME I (Table 6). Moreover, a highly significant $(\mathrm{p}<0.01)$ interaction was observed among CP percentage, ME, CP ${ }^{*} \mathrm{ME}$ and YI. These results are supported by the presence of significantly $(\mathrm{p}<0.05)$ positive correlation coefficients between YI and Lys I, as well as a highly significant $(\mathrm{p}<0.01)$ correlation coefficient between YI and Met + Cys. (Table 6).

\begin{tabular}{|c|c|c|c|c|c|c|c|c|c|c|}
\hline СР\% & Energy & ESG $\left(\mathrm{cm}^{3}\right)$ & YW (g) & $\mathrm{AW}(\mathrm{g})$ & & ESW (g) & YI & AI & ST (mm) & HU \\
\hline \multirow[t]{2}{*}{18.8} & Normal & $1.21^{\mathrm{a}}$ & $14.93^{\mathrm{a}}$ & $38.39 \mathrm{a}$ & & 6.97 & $0.41^{\mathrm{b}}$ & $0.31^{\mathrm{b}}$ & $0.33^{a}$ & $99.00^{\mathrm{b}}$ \\
\hline & low & $1.19 \mathrm{ab}$ & $14.81^{\mathrm{a}}$ & $38.09 a$ & & 6.96 & $0.39 \mathrm{~b}$ & $0.34^{a}$ & $0.33^{\mathrm{a}}$ & $99.51^{a}$ \\
\hline \multirow[t]{2}{*}{17} & Normal & $1.19^{a b}$ & $14.89^{a}$ & $37.45^{\mathrm{abc}}$ & & 6.99 & $0.37 \mathrm{~b}$ & $0.34^{a}$ & $0.32^{\mathrm{b}}$ & $98.97^{b}$ \\
\hline & low & $1.16^{\mathrm{b}}$ & $14.61^{a}$ & $36.47 \mathrm{bc}$ & & 6.94 & $0.37 \mathrm{~b}$ & $0.33^{\mathrm{a}}$ & $0.32^{\mathrm{b}}$ & $98.97^{b}$ \\
\hline \multirow[t]{9}{*}{15.5} & Normal & $1.17 \mathrm{~b}$ & $14.35^{\mathrm{ab}}$ & $36.92^{c}$ & & 6.98 & $0.49^{a}$ & $0.34^{a}$ & $0.31^{\mathrm{b}}$ & $98.97 \mathrm{~b}$ \\
\hline & low & 1.16 & $13.97 \mathrm{~b}$ & $37.26^{\mathrm{bc}}$ & & 7 & $0.37 \mathrm{~b}$ & $0.34^{a}$ & $0.32^{\mathrm{b}}$ & $98.95^{b}$ \\
\hline & $\operatorname{SEM}(n=4)^{a}$ & 0.01 & 0.09 & 0.15 & & 0.03 & 0.01 & 0.002 & 0.001 & 0.04 \\
\hline & & & & & & СР\% & & & & \\
\hline & 18 & $1.2^{\mathrm{a}}$ & $14.87 \mathrm{a}$ & $38.24^{\mathrm{a}}$ & 6.97 & & $0.39^{b}$ & $0.32^{b}$ & $0.33^{a}$ & $99.30^{\mathrm{a}}$ \\
\hline & 16 & $1.17^{\mathrm{b}}$ & $14.75 \mathrm{a}$ & $36.96^{\mathrm{b}}$ & 6.97 & & $0.37 \mathrm{~b}$ & $0.33^{\mathrm{ab}}$ & $0.32^{\mathrm{b}}$ & $98.97 \mathrm{~b}$ \\
\hline & 14 & $1.17^{b}$ & $14.16 \mathrm{~b}$ & $37.09 \mathrm{~b}$ & 6.99 & & $0.43^{a}$ & $0.34^{a}$ & $0.32^{\mathrm{b}}$ & $98.97 \mathrm{~b}$ \\
\hline & SEM $^{a}$ & 0.01 & 0.17 & 0.26 & 0.05 & & 0.01 & 0.003 & 0.002 & 0.1 \\
\hline & & & & & $\begin{array}{c}\text { E (Kcal } \\
\text { Kg) }\end{array}$ & & & & & \\
\hline Main effects & Normal & 1.2 & 14.72 & 37.59 & 6.98 & & $0.42^{\mathrm{a}}$ & 0.33 & $0.32^{\mathrm{b}}$ & 98.98 \\
\hline
\end{tabular}


Effect Of Different Protein And /Or Metabolizable Energy Levels in Diets Formulated Based on Ideal Protein Concept on Performance, Egg Production, And Egg Quality Traits of Layers During Phase 1 Of Egg Production

\begin{tabular}{|c|c|c|c|c|c|c|c|c|c|}
\hline & Low & 1.2 & 14.46 & 37.27 & 6.97 & $0.38^{\mathrm{b}}$ & 0.34 & $0.33 a$ & 99.15 \\
\hline & SEMa & 0.01 & 0.14 & 0.3 & 0.04 & 0.01 & 0.004 & 0.001 & 0.1 \\
\hline & $\mathrm{CP} \%$ & $*$ & $*$ & $* *$ & NS & $* *$ & $* *$ & $* *$ & $* *$ \\
\hline Probabilities & ME & NS & NS & NS & NS & $* *$ & NS & * & * \\
\hline & $\mathrm{CP} * \mathrm{ME}$ & NS & NS & NS & NS & $* *$ & $* *$ & $*$ & $*$ \\
\hline
\end{tabular}

NS = not significant. $\mathrm{a}-\mathrm{c}=$ means in a column not sharing a common letter are significantly different $(\mathrm{p}<0.05)$.

a pooled standard error of the mean ( $\mathrm{n}=$ number of replicates per treatment).

$0.05, * * \mathrm{P}<0.01$.

$\mathrm{EW}=$ egg weight, $\mathrm{ESG}=$ egg specific gravity, $\mathrm{YW}=$ yolk weight, $\mathrm{AW}=$ albumin weight, $\mathrm{ESW}=$ egg shell weight, $\mathrm{YI}=\mathrm{yolk}$ index $\mathrm{AI}=$ albumin index, ST = shell thickness, $\mathrm{HU}=$ haugh unit.

\begin{tabular}{|c|c|c|c|c|c|c|c|c|c|}
\hline Parameter & $\begin{array}{l}\text { FC } \\
\text { (g) }\end{array}$ & $\begin{array}{c}\text { FCR } \\
\text { (g fee/g egg mass }\end{array}$ & $\begin{array}{c}\text { PI } \\
\text { (g/hen/day) }\end{array}$ & $\begin{array}{c}\text { ME. I } \\
\text { (Kcal/kg) }\end{array}$ & $\begin{array}{c}\text { Lys.Ia } \\
\text { (g/hen/day) }\end{array}$ & $\begin{array}{l}\text { Met.+ cys.Ia } \\
\text { (g/hen/day }\end{array}$ & $\begin{array}{l}\text { HDEP } \\
\text { (\%) }\end{array}$ & $\begin{array}{l}\text { EW } \\
\text { (g) }\end{array}$ & $\begin{array}{c}\text { EM } \\
\text { (g/hen) }\end{array}$ \\
\hline $\mathrm{ESG}\left(\mathrm{cm}^{3}\right)$ & 0.68 & -0.11 & $0.81^{*}$ & $0.87^{*}$ & $0.86^{*}$ & 0.73 & 0.55 & $0.98^{* *}$ & $0.82^{*}$ \\
\hline YH (mm) & 0.67 & -0.19 & $0.82^{*}$ & $0.88^{*}$ & $0.85^{*}$ & 0.69 & 0.66 & $0.96^{* *}$ & $0.88^{*}$ \\
\hline AH (mm) & -0.34 & -0.07 & -0.50 & -0.56 & -0.57 & -0.41 & -0.23 & -0.63 & -0.43 \\
\hline YW (g) & 0.73 & -0.09 & 0.76 & $0.89 * *$ & 0.68 & 0.66 & $0.88^{*}$ & 0.64 & 0.88 \\
\hline AW (g) & 0.49 & 0.30 & 0.67 & 0.55 & 0.78 & 0.56 & 0.24 & $0.9^{* *}$ & 0.57 \\
\hline ESW (g) & -0.18 & -0.35 & -0.28 & -0.05 & -0.30 & -0.11 & -0.132 & -0.08 & -0.10 \\
\hline YI & 0.69 & -0.11 & $0.81^{*}$ & $0.87^{*}$ & $0.86^{*}$ & $0.73^{* *}$ & 0.55 & $0.98^{* *}$ & $0.82^{*}$ \\
\hline AI & -0.47 & -0.37 & -0.54 & -0.60 & -0.57 & -0.53 & 0.22 & -0.49 & -0.35 \\
\hline ST (mm) & $0.86^{*}$ & 0.42 & $0.89 * *$ & 0.76 & $0.95^{* *}$ & $0.89 * *$ & 0.40 & $0.83^{*}$ & 0.64 \\
\hline Haugh unit & 0.34 & -0.34 & 0.30 & 0.44 & 0.27 & 0.34 & 0.39 & 0.42 & 0.48 \\
\hline
\end{tabular}

ESG = Egg sp. Gravity, $\mathrm{YH}=$ Yolk height, $\mathrm{AH}=$ Albumin height, ESW = Egg shell weight, $\mathrm{YI}=$ Yolk index, $\mathrm{AI}=\mathrm{Albumin}$ index, $\mathrm{ST}=\mathrm{Shell}$ thickness.

$* \mathrm{P}<0.05 ; * * \mathrm{P}<0.01$

aStandard ilealy digestable amino acid basis.

\section{Economic efficiency study}

The results of the economic efficiency study are summarised in (Table 7). It was observed that the lowest cost diet (G3), defined as the diet with the lowest price $/ \mathrm{kg}$ feed, was 2.31 L.E., with a feed cost/hen of 28.64 L.E. The best total income (L.E.) was achieved in G1L (43.16 L.E.), while the least total income was obtained from G3L (38.75 L.E.). The best net revenue (L.E.) and E.E. (\%) were achieved in G3 (13.04; 0.46), while the net revenue and E.E. were obtained from CG1 $(6.75 ; 0.19)$. Regarding the price/kg feed (L.E.), reducing dietary energy by only $100 \mathrm{kcal} / \mathrm{kg}$ resulted in lowering the price/tonne feed by 71 L.E. in G1L compared to CG1. 
Similarly, price/tonne feed was reduced by 50 L.E. in G2L compared to G2. Similar feed prices were obtained in G3 and G3L. This may be due to a higher inclusion rate of yellow corn in diets formulated with higher levels of energy (CG1 and G2), which in turn increased the price $/ \mathrm{kg}$ feed. Lowering both the dietary CP and ME reduced the price $/ \mathrm{kg}$ feed. In other words, the highest price $/ \mathrm{kg}$ feed (L.E.) was found in CG1 (2.55), followed by G2L (2.34), then G3L (2.31). Similarly, feed cost/hen (L.E.) was reduced by decreasing the dietary ME in G1L compared to CG1 (34.45 vs 35.16). Feed cost/hen (L.E.) was higher in G2L compared to G2 (31.98 vs. 31.05), as well as in G3L compared to G3 (29.59 vs. 28.64). This could be the result of increased feed intake/hen (kg) in G2L and G3L, accompanied by feeding reduced levels of ME (100 $\mathrm{kcal} / \mathrm{kg}$ ). Additionally, reducing both dietary CP and ME energy decreased feed cost/hen (L.E.), as the highest diet cost/hen (L.E.) was found in CG1, G2L, and G3L (35.16, 31.98, 29.59, respectively). Moreover, the highest total income (L.E.) was achieved in G1L (43.16), followed by G2 (42.28), and the least total income was obtained in G3L (38.75). This may be due to the fact that the highest egg number/ hen was in G1L (77.07) followed by G2 (75.51), and the least egg number/hen was in G3L (69.19). Net revenue (L.E.) was the highest (11.23 and 13.04) in birds fed reduced CP diets with a normal level of energy (G2 and G3). Similarly, EE (\%) was the highest in G3 (0.46) followed by G2 (0.36). The lowest economic efficiency was obtained in CG1 (0.19). Failure of birds fed reduced CP diets with reduced levels of ME (G2L and G3L) to be more economically efficient than birds fed the same levels of dietary CP with higher levels of ME (G2 and G3), may be due to the higher feed cost/hen and the lower egg number/hen associated with these diets. Analysing the REE (\%) data revealed that the REE of G1L (\% of CG1) was higher than CG1 by 31.57 $\%$. On the contrary, the REE of G2L (\% of G2) was lower than G2 by $22.22 \%$. In the same vein, the REE of G3L (\% of G3) was lower than G3 by $32.61 \%$. From the aforementioned results, it can be concluded that reduced CP diets with a normal level of ME (G2 and G3) were the most economically efficient diets, as their prices were $18.8 \%$ lower than higher energy level diets, but at the same time did not affect layer hen performance (egg number/hen). Gunawardana et al. (2008) claimed that the highest profits were achieved at $17.38 \%$ protein content and $2580 \mathrm{kcal} / \mathrm{kg} \mathrm{ME}$ level for the lowest price of oil. On the other hand, as for highest prices of oil, the best profits were received for highest protein and lowest dietary energy contents.

Table 7 Economic efficiency study of the six diets fed to laying hens at the end of the experimental trial

\begin{tabular}{|c|c|c|c|c|c|c|c|c|}
\hline \multirow{4}{*}{$\begin{array}{c}\text { Dietary } \\
\text { treatment } \\
\quad s\end{array}$} & Input & & & Output & & & & \\
\hline & $\begin{array}{c}\text { Feed } \\
\text { intake/he } \\
\text { n }\end{array}$ & $\begin{array}{l}\text { Price } / K \\
\text { g feed }\end{array}$ & $\begin{array}{c}\text { Feed } \\
\text { cost/he } \\
n\end{array}$ & $\begin{array}{c}\text { Egg } \\
\text { number/he } \\
\text { n }\end{array}$ & $\begin{array}{c}\text { Total } \\
\text { incom } \\
\text { e }\end{array}$ & $\begin{array}{c}\text { Net } \\
\text { revenu } \\
\text { e }\end{array}$ & & \\
\hline & (Kg) & (L.E) & (L.E) & & (L.E) ${ }^{1}$ & (L.E) & $\mathbf{E E}^{2}$ & REE $^{3}$ \\
\hline & & & & & & & $(\%)$ & (\%) \\
\hline CG1 & 13.79 & 2.55 & 35.16 & 74.85 & 41.91 & 6.75 & $\begin{array}{c}0.1 \\
9\end{array}$ & 100 \\
\hline G1L & 13.89 & 2.48 & 34.45 & 77.07 & 43.16 & 8.71 & $\begin{array}{c}0.2 \\
5\end{array}$ & $\begin{array}{c}131.5 \\
7\end{array}$ \\
\hline G2 & 13.47 & 2.39 & 31.05 & 75.51 & 42.28 & 11.23 & $\begin{array}{c}0.3 \\
6\end{array}$ & 100 \\
\hline G2L & 13.67 & 2.34 & 31.98 & 73.09 & 40.93 & 8.95 & $\begin{array}{c}0.2 \\
8\end{array}$ & 77.78 \\
\hline G3 & 12.4 & 2.31 & 28.64 & 74.43 & 41.68 & 13.04 & $\begin{array}{c}0.4 \\
6\end{array}$ & 100 \\
\hline
\end{tabular}




\section{G3L}

1Total income= Egg number $/$ hen $\times$ price of one egg $(0.56$ L. E)

$2 \mathrm{Economic}$ efficiency $=$ net revenue (total income - feed cost $) /$ feed cost

3 Relative economic efficiency $=($ EE treatment $/$ EE control $($ CG18 or CG16 or CG14) $) \times 100$

\section{CONCLUSIONS AND RECOMMENDATIONS}

In conclusion, as the amino acid composition in the formulated diet satisfied the growth, maintenance, and egg production requirements of layers less nitrogen should be excreted in the feaces. The optimization of dietary amino acid profiles and ME for layer hens using the "ideal protein concept" provides an economically and environmentally feasible method to formulate layer diets for peak performance. In this study, layer hens showed positive responses to reduced CP diets prepared in accordance with the "ideal protein concept." Our data have shown that growth performance parameters, external and internal egg quality traits, and environmental pollution were all positively influenced by lower CP diets. Furthermore, we showed that these diets were also economically feasible.

\section{Ethical Approval}

This current experimental feeding trial was held in Henz farm for egg production located at Cairo-Alexandria desert road - Egypt and its protocol was approved by the Institutional Animal Care and Use Committee of Cairo University (Vet.Cu.IACUC) with approval number (Vet Cu 20022020133).

\section{REFERENCES}

Aduku AO. (2004) Animal nutrition in the tropics, Davcon Co.; Zaria; p.52.

Aletor VA, Hamid II, Nieß E, Pfeffer E. (2000) Low-protein amino acid-supplemented diets in broiler chickens: effects on performance, carcass characteristics, whole-body composition and efficiencies of nutrient utilisation. Journal of the Science of Food and Agriculture; 80:547-554. Retrieved from https://doi.org/10.1002/(SICI)1097-0010(200004)80:5<547::AIDJSFA531>3.0.CO;2-C

Almeida V R, Dias AN, Bueno CFD, Couto FAP, Rodrigues PA, Nogueira WCL, Faria FDE. (2012) Crude protein and metabolizable energy levels layers reared in hot climates. Brazilian Journal of Poultry Science; 14:159-232. Retrieved from https://doi.org/10.1590/S1516-635X2012000300007

Bohnsack CR, Harms RH, Merkel WD, Russell GB. (2002) Performance of commercial layers when fed diets with four levels of corn oil or poultry fat. Journal of Applied Poultry Research; 11:68-76. Retrieved from https://doi.org/10.1093/japr/11.1.68

Deaton JW, Reece FN, Lott BD. (1982) Effect of atmospheric ammonia on laying hen performance. Poultry Science; 61:1815-1817. Retrieved from https://doi.org/10.3382/ps.0611815

Ding Y, Bu X, Zhang N, Li L, Zou X. (2016) Effects of metabolizable energy and crude protein levels on laying performance, egg quality and serum biochemical 
indices of Fengda -1 layers. Animal Nutrition; 2:93-98. Retrieved from https://doi.org/10.1016/j.aninu.2016.03.006

Elwinger K, Tufvesson M, Lagerkvist G, Tauson R. (2008) Feeding layers of different genotypes in organic feed environments. British Poultry Science; 49:654665. Retrieved from https://doi.org/10.1080/00071660802491519

Grobas S, Mendez J, De Blas C, Mateos GG. (1999) Laying hen productivity as affected by energy, supplemental fat, and linoleic acid concentration of the diet. Poultry Science; 78:1542-1551. Retrieved from https://doi.org/10.1093/ps/78.11.1542

Gunawardana P, Ronald DA, Bryant MM. (2008) Effect of energy and protein on performance, egg components, egg solids, egg quality and profits in molted Hy-Line W-36 Hens. Journal of Applied Animal Research; 17:432-439. Retrieved from https://doi.org/10.3382/japr.2007-00085

Gunawardana P, Wu G, Yuan K, Bryant MM, Roland Sr DA. (2009) Effect of dietary protein and peptide in corn-soy diets on hen performance, egg solids, egg composition and egg quality of Hy-Line W36 hens during second cycle phase three. International Journal of Poultry Science; 8:317-322. Retrieved from https://doi.org/10.3923/ijps.2009.317.322

Gunawardan P, Wu G, Yuan K, Bryant MM, Roland DA. (2007) Effect of dietary energy and protein on performance, egg composition, egg solids, egg quality and profits of hy-line $\mathrm{W}-36$ hens during phase 2. International Journal of Poultry Science; 6:739-744. Retrieved from https://doi.org/10.3923/ijps.2007.739.744

Harms RH, Russell GB, Sloan DR. (2000) Performance of four strains of commercial layers with major changes in dietary energy. Journal of Applied Poultry Research; 9:535-541. Retrieved from https://doi.org/10.1093/japr/9.4.535

Ji F, Fu SY, Ren B, Wu SG, Zhang HJ, Yue HY, Gao Helmbrecht A, Qi GH. (2014) Evaluation of amino-acid supplemented diets varying in protein levels for laying hens. Journal of Applied Poultry Research; 23:384-392. Retrieved from https://doi.org/10.3382/japr.2013-00831

Keshavarz K, Jackson ME. (1992) Performance of growing pullets and laying hens fed low-protein, amino acid- supplemented diets. Poultry Science; 71:905918. Retrieved from https://doi.org/10.3382/ps.0710905

Keshavarz K. (1998) The effect of light regimen, floor space and energy and protein levels during the growing period on body weight and early egg size. Poultry Science; 77:1266-1279. Retrieved from https://doi.org/10.1093/ps/77.9.1266

Koelkebeck KW, Parsons CM, Moshtaghian J. (1993) Effect of protein and methionine levels in molt diets and post molt performance of laying hens. Poultry Science; 70:2063-2073. Retrieved from https://doi.org/10.3382/ps.0702063

Larbier M, Leclercq B. (2000) Nutrition and Feeding of Poultry, Nottingham University Press, Loughborough; p. 305. Retrieved from https://www.cabdirect.org/cabdirect/abstract/19946796719

Leeson S, Summers JD, Diaz GJ. (2000) Nutrición Aviar Comercial. Santafé deBogotá, Colombia; p.359. Retrieved from http://www.sidalc.net/cgibin/wxis.exe/?IsisScript=bac.xis\&method=post\&formato=2\&cantidad=1\& expresion $=\mathrm{mfn}=044715$ 
Liu Z, Wu G, Bryant MM, Roland DA. (2005) Influence of added synthetic lysine in low-protein diets with the methionine plus cysteine to lysine ratio maintained at 0.75. Journal of Applied Poultry Research; 14:174-182. Retrieved from https://doi.org/10.1093/japr/14.1.174

Mackie RI, Stroot PG, Varel VH. (1998) Biochemical identification and biological origin of key odor components in livestock waste. Journal of Animal Science; 76:1331-1342. Retrieved from https://doi.org/10.2527/1998.7651331x

Mendonca CX, Lima FR. (1999) Effect of dietary protein and methionine levels on forced molted performance of laying hens. Brazilian Journal of Veterinary Research Animal and Science; 36:332-338. Retrieved from https://www.scielo.br/j/bjvras/a/LcYYW4TN8ddsVwJvqzTWhqS/?lang=p $\mathrm{t}$

Moore PA. (1998) Best management practices for poultry manure utilization that enhance agricultural productivity and reduce pollution. In: J.L. Hatfield and B. Stewart (eds.) Animal waste utilization: Effective use of manure as a soil resource. Ann Arbor Press, Chelsea, MI; 89-123. Retrieved fromhttps://doi.org/10.1201/9781439822630.ch5

Morse D. (1995) Environmental considerations of livestock producers. Journal of Animal Science; 73:2733-2740. Retrieved from https://doi.org/10.2527/1995.7392733x

Mousavi SN, Khalaji S, Ghasemi-Jirdehi A, Foroudi F. (2013) Investigation on the effects of various protein levels with constant ratio of digestible sulfur amino acids and threonine to lysine on performance, egg quality and protein retention in two strains of laying hens. Italian Journal of Animal Science; 12:9-15. Retrieved from https://doi.org/10.4081/ijas.2013.e2

Nahashon SN, Adefope N, Amenyenu A, Wright D. (2006) Effect of varying metabolizable energy and crude protein concentrations in diets of Pearl Grey guinea fowl pullets: 1. Growth performance. Poultry Science; 85:18471854. Retrieved from https://doi.org/10.1093/ps/85.10.1847

Nahashon SN, Adefope NA, Amenyenu A, Wright D. (2007) Effect of varying concentrations of dietary crude protein and metabolic energy on laying performance of Pearl Grey guinea fowl hens. Poultry Science; 86:1793-1799. Retrieved from https://doi.org/10.1093/ps/86.8.1793

Novak C, Yakout H, Scheideler S. (2004) The combined effects of dietary lysine and total sulfur amino acid level on egg production parameters and egg components in Dekalb Delta laying hens. Poultry Science, 83:977-984. Retrieved from https://doi.org/10.1093/ps/83.6.977

Novak C, Yakout HM, Scheideler SE. (2006) The effect of dietary protein level and total sulfur amino acid: Lysine ratio on egg production parameters and egg yield in Hy-Line W-98 hens. Poultry Science; 85:2195-2206. Retrieved from https://doi.org/10.1093/ps/85.12.2195

Olorede BR. (1998) Sheabutter cake as an unconventional feed ingredient in the diet of layer and broilers. Ph. D Thesis University of Ibadan.

Patterson P. (2001) Using Dietary and Management Strategies to Reduce the Nutrient Excretion of Poultry. Reprinted from Livestock and Poultry Environmental Stewardship curriculum, lesson authored by Paul Patterson, the Pennsylvania State University, courtesy of MidWest Plan Service, Iowa State University, Ames, Iowa 50011-3080; Copyright (C) 2001. 
Rose SP, Craig L, Pritchard S. (2004) A comparison of organic laying hen feed formulations. British Poultry Science ; 45:S63. Retrieved from https://doi.org/10.1080/00071660410001698380

Summers JD. (1993) Reducing nitrogen excretion of the laying hen by feeding lower crud.e protein diets. Poultry Science ; 72:1473-1478. Retrieved from https://doi.org/10.3382/ps.0721473

Summers JD Leeson S (1994). Laying hen performance as influenced by protein intake to sixteen weeks of age and body weight at point of lay. Poultry Science ; 73:495-501. Retrieved from https://doi.org/10.3382/ps.0730495

Sell JL, Angel CR, Escribano F. (1987) Influence of supplemental fat on weight of eggs and yolks during early egg production. Poultry Science ; 66:1807-1812. Retrieved from https://doi.org/10.3382/ps.0661807

Shaimaa R, Maha M, Ramadan A, Tarek M. (2015) Impact of reduced protein diets based on ideal amino acid profile on performance and egg quality traits of laying hens. International Journal of Services Technology and Management; 4:220-229.

Simkiss K, Taylor TG. (1971) Physiology and biochemistry of domestic fowl. 3rd ed. Academic Press, London.

Sohail SS, Bryant MM, Roland DA. (2003) Influence of dietary fat on economic returns of commercial Leghorns. Journal of Applied Poultry Research; 12:356-361. Retrieved from https://doi.org/10.1093/japr/12.3.356

Summers JD, Leeson S. (1983) Factors influencing early egg size. Poultry Science ; 62:1155-1159. Retrieved from https://doi.org/10.3382/ps.0621155

Summers JD, Leeson S. (1993) Influence of diets varying in nutrient density on the development and reproductive performance of White Leghorn pullets. Poultry Science; 72:1500-1509. Retrieved from https://doi.org/10.3382/ps.0721500

Wu G, Bryant MM, Voitle RA, Roland DA. (2005) Effect of dietary energy on performance and egg composition of bovanswhite and dekalb white hens during Phase I. Poultry Science ; 84:1610-1615. Retrieved from https://doi.org/10.1093/ps/84.10.1610

Yu DJ, Na JC, Choi HC, Bang HT, Kim AH. (2008) Effects of varying levels of dietary metabolizable energy and crude protein on performance and egg quality of organic laying hens. Korean Journal of Poultry Science ; 35:367-373. Retrieved from https://doi.org/10.5536/KJPS.2009.35.4.367

Zanaty GA. (2006) Optimum dietary protein and energy levels for Norfa hens during the laying period. Egyptian Poultry Science Journal ; 26:207-220 